\title{
Geotechnical Research
}

\section{Award-winning paper in 2017}

Papers published in Geotechnical Research are eligible for awards from the Institution of Civil Engineers. Papers from any of the ICE journals can be nominated for several awards. In addition, each journal has awards dedicated to their specific subject area.

On Monday 8 October 2018, ICE president Robert Mair presented an award to the following paper published in Geotechnical Research in 2017. The editorial panel nominated their best papers and an awards committee chaired by Nigel Wright allocated the awards.

\section{Thomas Telford Premium Prize}

The Thomas Telford Premium Prize, presented for the best paper published in Geotechnical Research, was awarded to Butterfield and Marchi (2017).

\section{Abstract}

There is mounting evidence in favour of replacing the e against $\log _{10}\left(\sigma_{v}^{\prime}\right)$ diagram, conventionally used to represent soil compressibility in an oedometer, with a $\log (v)$ against $\log \left(\sigma_{v}^{\prime}\right)$ diagram, which significantly improves the linearity of virgin loading and unloading paths. This paper presents a simple, new formulation of the 'intrinsic' compression and 'sedimentation' compression lines for a range of insensitive, sedimentary marine clays presented in Burland's 1990 Rankine Lecture by using a log(v) against $\log \left(\sigma_{v}^{\prime}\right)$ interpretation of the data.

\section{REFERENCES}

Butterfield R and Marchi M (2017) The compressibility of natural and reconstituted marine clays. Geotechnical Research 4(3): 172-177,

https://doi.org/10.1680/jgere.17.00010.

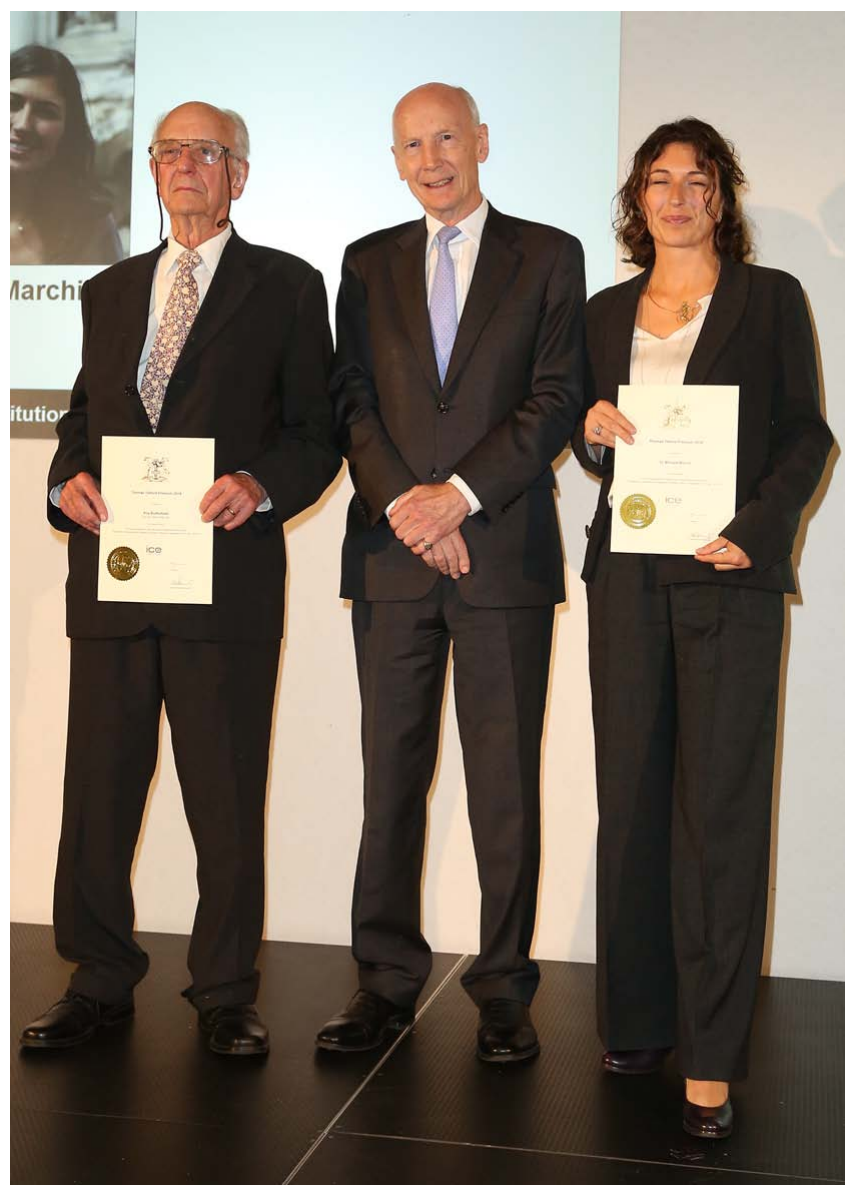

Thomas Telford Premium Prize winners Roy Butterfield and Michela Marchi with ICE president Robert Mair (centre) 